\title{
Penetration and Metabolism of Bicyclic Phosphorus Esters Which Affect Their Insecticidal Activity against the Housefly
}

\author{
Yoshihisa Ozoe, Hiroyuki Karino, Kazuo Mochida, \\ Toshiie NAKamura and Makoto FujII \\ Department of Environmental Sciences, Shimane University, \\ Nishikawatsu-cho, Matsue 690, Japan
}

(Received December 16, 1985)

\begin{abstract}
Pretreatment with the microsomal oxidase inhibitor piperonyl butoxide (pb) greatly improved the topical insecticidal activity of the GABA antagonist, 4- $n$-propyl-2,6,7-trioxa-1phosphabicyclo[2.2.2] octane 1-oxide (4- $n$-propyl BP), ${ }^{*}$ against the housefly, Musca domestica L., when the synergistic ratio was 313 . The insecticidal activity was also enhanced by bypassing the integument with injection without $\mathrm{pb}$ pretreatment. When tested by four different methods, the order of the $24-\mathrm{hr} \mathrm{LD}_{50}$ values $(\mu \mathrm{g} / \mathrm{fly})$ for $4-n$-propyl BP was: injection, pretreated with $\mathrm{pb}(0.169)<$ topical application with $\mathrm{pb}(0.212)<$ injection $(0.449) \ll$ topical application (66.4). Penetration studies indicated that 4- $n$-propyl BP caused marked mortality at the internal level of $0.2-0.3 \mu \mathrm{g}$ per fly, although the penetration was slow. The topically applied thiono and phosphite analogs without $\mathrm{pb}$ were approximately as insecticidal as the oxon analog injected. The thiono analog had the lowest $24-\mathrm{hr} \mathrm{LD}_{50}$ value (with $\mathrm{pb}$ ) among its analogs, which was $0.061 \mu \mathrm{g}$ per fly. The lethal level of the thionate ester in the housefly body was estimated to be one-tenth of that of 4-n-propyl BP. The difference in the internal lethal level between 4- $n$-propyl BP and its thiono analog seems to be related to the difference in their insecticidal activity when they are topically applied without $\mathrm{pb}$.
\end{abstract}

\section{INTRODUCTION}

Bicyclic phosphorus esters described here are a group of compounds possessing a structure of 2,6,7-trioxa-1-phosphabicyclo[2.2.2]octane, including phosphites, phosphates and phosphorothionates. These esters with appropriate substituents are neurotoxic to insects as well as to mammals. ${ }^{1,2)}$ The compounds are different from usual organophosphorus insecticides and quite unique in that they interfere with the inhibitory neurophysiological action of $\gamma$-aminobutyric acid (GABA) in synapses. ${ }^{3-5)}$ Also, it is likely that their GABA antagonistic action results from the blockade

* Bicyclic phosphates are abbreviated as BPs; e.g., 4-n-propyl-2, 6, 7-trioxa-1-phosphabicyclo [2.2.2]octane 1-oxide (2) is referred to as 4-n-propyl BP. of chloride ion channels caused by binding noncovalently to a synaptic site for a plantorigin toxicant picrotoxinin, although there is no conclusive evidence for it such as BP inhibition of chloride uptake. ${ }^{6-8)}$

We studied the structure-insecticidal activity relationship of bicyclic phosphates with the housefly, Musca domestica L., as a part of research on the GABA neurotransmission system of insects. ${ }^{2}$ Our findings showed that bicyclic phosphates topically applied without any synergists were inactive as insecticides, while they exerted insecticidal activity by injection. The inactivity by topical application was ascribed to their low penetration rate to the housefly body. The present study was initiated to evaluate the influence of penetration and detoxication factors on the insecticidal activity of bicyclic phosphorus esters. 


\section{MATERIALS AND METHODS}

\section{Chemicals}

Bicyclic phosphorus esters were prepared by procedures previously described. ${ }^{9)}$ Piperonyl butoxide (pb) was purchased from Tokyo Kasei Kogyo Co., Ltd.

\section{Treatment of Houseflies}

An acetone solution ( $1 \mu \mathrm{l} / \mathrm{fly}$ ) of bicyclic phosphorus esters was topically applied on the mesonotum of an adult female housefly (3-5 days old) which had been lightly anesthetized with carbon dioxide. When used, an acetone solution of $\mathrm{pb}(10 \mu \mathrm{g} / \mathrm{l} \mu \mathrm{l} / \mathrm{fly})$ was similarly applied $1 \mathrm{hr}$ prior to a toxicant application. After treatment, 15 flies were immediately released in a glass jar $(5.8 \mathrm{~cm}$ in diameter and $10.5 \mathrm{~cm}$ in height) containing a cotton pad soaked with sucrose solution, and held at $25^{\circ} \mathrm{C}$ and $50 \%$ R. H. under continuous lighting. Triplicate groups of 15 houseflies were used for each dosage to determine $\mathrm{LD}_{50}$ values. In penetration studies, a group of 15 treated houseflies were removed from the jars at appropriate time intervals and were washed with successive portions of acetone $(30 \mathrm{ml}$ of total volume). Then, the rinsed houseflies were transferred into a mortar and ground in acetone with a pestle. Further homogenization was performed with a Teflon-glass homogenizer. The total volume of acetone used for this procedure was $50 \mathrm{ml}$, including acetone for rinsing of glasswares etc.

\section{Cleanup of Extracts}

The acetone rinse of the housefly surfaces was concentrated to about $1 \mathrm{ml}$ under reduced pressure below $50^{\circ} \mathrm{C}$, and then brought to dryness with a gentle jet of air. The residue was transferred into a separatory funnel alternately with three $10-\mathrm{ml}$ portions of hexane and of hexane-saturated acetonitrile, and the funnel was shaken for $10 \mathrm{~min}$. The layer $(30$ $\mathrm{ml}$ ) of hexane-saturated acetonitrile was concentrated in vacuo below $50^{\circ} \mathrm{C}$ until most of the solvent was eliminated, and then the remaining solvent was evaporated to dryness with a fine stream of air. The residue was transferred into another separatory funnel with chloroform (30 $\mathrm{ml}$ of total volume), to which $10 \%(\mathrm{w} / \mathrm{v}) \mathrm{NaCl}$ solution $(20 \mathrm{ml})$ was added, and then the funnel was shaken for 10 min. Extraction with chloroform was repeated three times and the combined chloroform layer was concentrated in a similar manner after being dried over anhydrous sodium sulfate ("external"). This procedure gave $95.0 \%$ and $90.2 \%$ recoveries for $4-n$-propyl BP (2) and its thiono analog (5) in control experiments, respectively.

The acetone homogenate of houseflies was filtered to remove debris through Toyo No. 2 filter paper on which sea sand (20-50 mesh) was placed. Other procedures were the same used for the "external" fraction except that fatty materials were removed with a $30-\mathrm{ml}$ portion and additional two $20-\mathrm{ml}$ portions of hexane. This extract from fly bodies is referred to as the "internal" fraction. The recoveries were $87.0 \%$ and $81.7 \%$ for $\mathbf{2}$ and $\mathbf{5}$ in control experiments, respectively.

The inside walls of the jars, in which treated flies were held, were washed with acetone (40 $\mathrm{ml}$ of total volume) to collect residues excreted or brushed off by the flies. The samples were cleaned up similarly to the "external" fraction, being designated as the "deposited" fraction.

No loss of 2 was observed when the compound $(15 \mu \mathrm{g})$ was kept on a glass plate at $25^{\circ} \mathrm{C}$ during the period of bioassay. Hence, it was concluded that the loss of $\mathbf{2}$ by volatilization from the housefly body was negligible.

\section{Chemical Analysis}

An appropriate volume of acetone was added to the cleaned-up residue. The amounts of the parent compounds, $\mathbf{2}$ and $\mathbf{5}$, were determined with a Shimadzu GC-7A gas chromatograph equipped with an FTD-8 (Rb) detector. The conditions of analysis were: a $3 \mathrm{~mm} \times 1 \mathrm{~m}$ glass column packed with $3 \% \mathrm{OV}-17$ on Chromosorb W (AW-DMCS), 80/100 mesh; column temp., $260^{\circ} \mathrm{C}$; injection temp., $290^{\circ} \mathrm{C}$ or $300^{\circ} \mathrm{C}$; the flow rate of carrier gas helium, $30 \mathrm{ml} / \mathrm{min}$. An acetone solution of $5 \mathrm{ppm}$ 4-(1-hydroxyethyl)-2,6, 7-trioxa-1-phosphabicyclo[2.2.2] octane 1-sulfide (7) was used as an internal standard. The retention times of $\mathbf{2}$, 5 and 7 were $1.0 \mathrm{~min}, 0.9 \mathrm{~min}$ and $1.5 \mathrm{~min}$ under the above conditions, respectively. 


\section{RESULTS}

\section{Insecticidal Activity}

Table 1 summarizes the insecticidal activity of various bicyclic phosphorus esters determined by four different methods. As described in our earlier paper, ${ }^{2)} 4-n$-propyl BP was extremely low in insecticidal activity by topical application without any synergists. However, it was found that $\mathrm{LD}_{50}$ values for $\mathbf{2}$ decreased with the elapse of time after topical application (Fig. 1). Also, the pretreatment of houseflies with the microsomal oxidase inhibitor piperonyl butoxide (pb) enhanced its insecticidal activity up to a level comparable to that determined by injection. The synergistic ratio was 313 . When tested by four different meth-

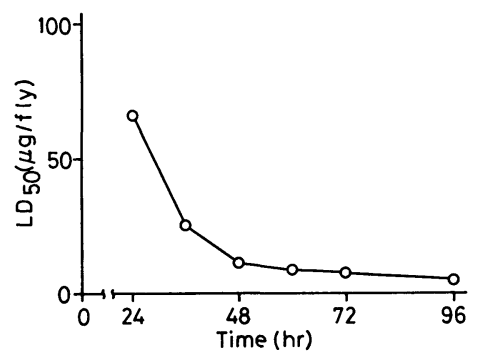

Fig. 1 Topical $\mathrm{LD}_{50}$ values of 4 - $n$-propyl BP determined at various intervals after application without synergists. ods, the toxicity of $\mathbf{2}$ was in the following order: injection, pretreated with $\mathrm{pb}>$ topical application with $\mathrm{pb}>$ injection $\gg$ topical application.

As for the 4-n-propyl thiono (5) and phosphite $(\mathbf{6})$ analogs, a topical application method was effective, even without pb. Compounds 5 and $\mathbf{6}$ by topical application were as active as compound $\mathbf{2}$ by injection. Especially $\mathbf{5}$ with $\mathrm{pb}$ was most potent among bicyclic phosphorus analogs already reported. ${ }^{2)}$ The synergistic ratios of $\mathbf{5}$ and $\mathbf{6}$ with pb were 4.59 and 2.18 , respectively. Included in Table 1 for comparison are the $\mathrm{LD}_{50}$ values of the most active oxon analog $\mathbf{3}$ and the GABA antagonist picrotoxinin.

\section{Penetration, Accumulation and Mortality}

Figure 2 shows the plots of the percentages of internal, external 4-n-propyl BP (2) and the compound deposited in jars against time (topical application without $\mathrm{pb}, 1 \mu \mathrm{g} / \mathrm{fly}$ ). The percentage of total recovery of $\mathbf{2}$ depicted by a dotted line gradually declined with the elapse of time. The disappearance of $\mathbf{2}$ is considered to be due to metabolism. The integument penetration of $\mathbf{2}$ was found to be slow, judged from the recovery from the housefly surface. It took 2-3 days for $50 \%$ of 2 to be absorbed. Firstorder plots of amount of external $\mathbf{2}$ indicated that the penetration proceeded in a biphasic

Table 1 Insecticidal activity of bicyclic phosphorus compounds to houseflies.

\begin{tabular}{|c|c|c|c|c|c|c|}
\hline \multirow[b]{3}{*}{ No. } & \multirow{2}{*}{\multicolumn{2}{|c|}{$R^{1} \stackrel{R}{2}_{-0^{\prime} x}$}} & \multirow[b]{3}{*}{$\mathrm{X}$} & \multicolumn{2}{|c|}{$\mathrm{LD}_{50} \quad(\mu \mathrm{g} / \mathrm{fly})$} & \multirow{3}{*}{ Synergistic ratio } \\
\hline & & & & \multirow[t]{2}{*}{ Alone } & \multirow[t]{2}{*}{ With $\mathrm{pb}$} & \\
\hline & $\mathrm{R}^{1}$ & $\mathrm{R}^{2}$ & & & & \\
\hline \multicolumn{7}{|c|}{ Injection ${ }^{\text {a) }}$} \\
\hline $\mathbf{1}$ & $t-\mathrm{C}_{4} \mathrm{H}_{9}$ & $\mathrm{H}$ & $\mathrm{P}=\mathrm{O}$ & 0.705 & 0.124 & 5.69 \\
\hline 2 & $n-\mathrm{C}_{3} \mathrm{H}_{7}$ & $\mathrm{H}$ & $\mathrm{P}=\mathrm{O}$ & 0.449 & 0.169 & 2.66 \\
\hline 3 & $n-\mathrm{C}_{3} \mathrm{H}_{7}$ & $\mathrm{CH}_{3}$ & $\mathrm{P}=\mathrm{O}$ & $\mathrm{NT}^{\mathrm{b})}$ & 0.102 & - \\
\hline 4 & & Picrotoxinin & & NT & 0.106 & - \\
\hline \multicolumn{7}{|c|}{ Topical application } \\
\hline 2 & $n-\mathrm{C}_{3} \mathrm{H}_{7}$ & $\mathrm{H}$ & $\mathrm{P}=\mathrm{O}$ & 66.4 & 0.212 & 313 \\
\hline 5 & $n-\mathrm{C}_{3} \mathrm{H}_{7}$ & $\mathrm{H}$ & $\mathrm{P}=\mathrm{S}$ & 0.276 & 0.061 & 4.59 \\
\hline 6 & $n-\mathrm{C}_{3} \mathrm{H}_{7}$ & $\mathrm{H}$ & $\mathrm{P}$ & 0.468 & 0.215 & 2.18 \\
\hline
\end{tabular}

a) Taken from Ref. 2) for comparison.

b) Not tested. 


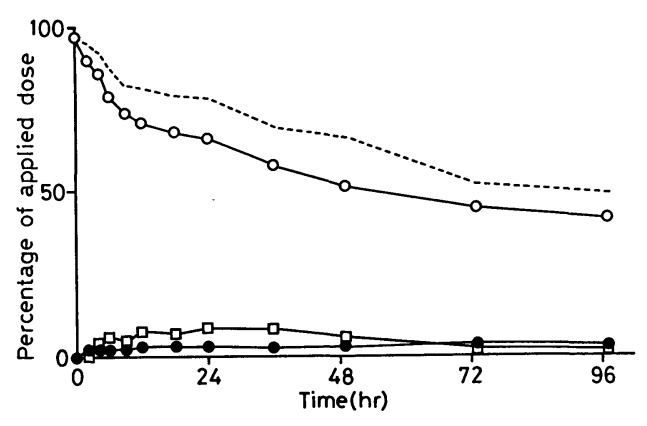

Fig. 2 Time course of penetration, accumulation and deposition of 4- $n$-propyl BP.

Totally recovered $(\cdots . .$.$) , external (\bigcirc-\bigcirc)$, internal (-๑) and deposited ( $\square-\square)$ 4-n-propyl $\mathrm{BP}$ are represented in the case of topical application at the dosage of $1 \mu \mathrm{g} / \mathrm{fly}$ without synergists.
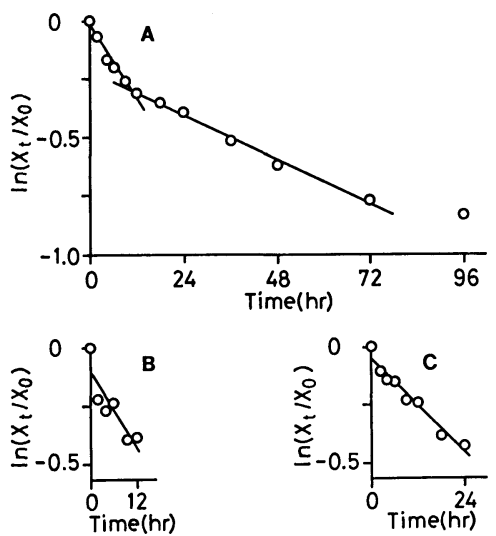

Fig. 3 First-order plots of 4-n-propyl BP (A: $1 \mu \mathrm{g} / \mathrm{fly}$, alone; $\mathrm{B}: 1 \mu \mathrm{g} / \mathrm{fly}$, with $\mathrm{pb})$ and its thiono analog (C: $1 \mu \mathrm{g} / \mathrm{fly}$, alone) recovered in the external fraction when topically applied.

$\mathrm{X}_{0}$ : amounts of $\mathrm{BP}$ at $0 \mathrm{hr}, \mathrm{X}_{t}$ : amounts of $\mathrm{BP}$ at $t \mathrm{hr}$.

manner with steep $\left(t_{1 / 2}=26 \mathrm{hr}\right)$ and gentle $\left(t_{1 / 2}=114 \mathrm{hr}\right.$ ) slopes (Fig. 3A).

Figure 4 shows the time course of the accumulation of $\mathbf{2}$ in the fly body and that of the housefly mortality when $\mathbf{2}$ was topically applied at $1 \mu \mathrm{g}$ per fly (A) and $5 \mu \mathrm{g}$ per fly (B). The internal amount of 2 reached ca. $0.04 \mu \mathrm{g}$ per fly and ca. $0.16 \mu \mathrm{g}$ per fly at $96 \mathrm{hr}$ when treated with $1 \mu \mathrm{g}$ per fly and $5 \mu \mathrm{g}$ per fly, respectively. At these dosages, $\mathbf{2}$ caused no or little mortality during the $96-\mathrm{hr}$ period of

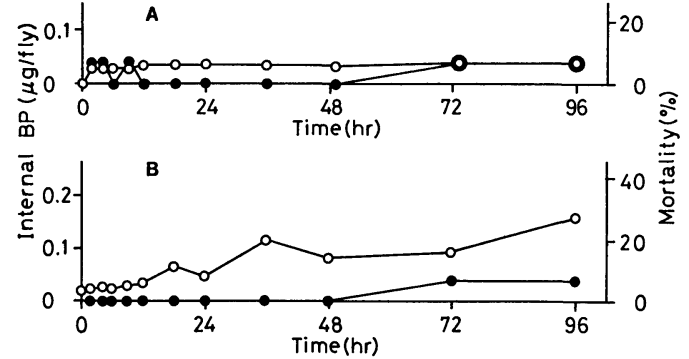

Fig. 4 Amounts of internal 4- $n$-propyl BP (०) and mortality of houseflies ( ) at the dosages of $1 \mu \mathrm{g} / \mathrm{fly}$ (A) and $5 \mu \mathrm{g} / \mathrm{fly}$ (B) during the $96-\mathrm{hr}$ period of bioassay.

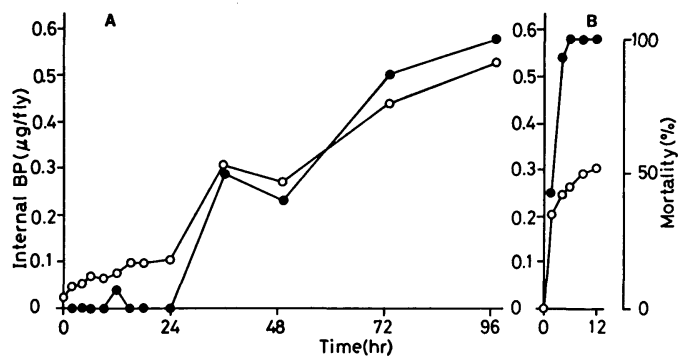

Fig. 5 Time course of internal accumulation of 4-n-propyl BP (O) and mortality of houseflies (o) when topically applied at the dosages of $12 \mu \mathrm{g} /$ fly without $\mathrm{pb}(\mathrm{A})$ and of $1 \mu \mathrm{g} / \mathrm{fly}$ with $\mathrm{pb}$ (B).

assay. By contrast, treatment with $12 \mu \mathrm{g}$ per fly markedly increased both the internal accumulation and mortality after $24 \mathrm{hr}$ (Fig. 5A). Mortality attained about $50 \%$ when the internal accumulation level reached approximately $0.3 \mu \mathrm{g}$ per fly. After $96 \mathrm{hr}$, the level of internal 2 increased to about $0.52 \mu \mathrm{g}$ per fly to result in $100 \%$ mortality. When houseflies were pretreated with $10 \mu \mathrm{g}$ of $\mathrm{pb}$ per fly prior to treatment with $1 \mu \mathrm{g}$ of $\mathbf{2}$ per fly, the level of internal 2 reached $0.26 \mu \mathrm{g}$ per fly, which resulted in 100\% mortality as early as $6 \mathrm{hr}$ (Fig. $5 \mathrm{~B}$ ). The amount of 2 that penetrated into the fly body was slightly larger in pbtreated flies than in untreated ones at the dosage of $1 \mu \mathrm{g}$ per fly. However, the difference does not seem to be significant. The penetration rate was little influenced by pb treatment (Figs. $3 \mathrm{~A}$ and $3 \mathrm{~B}$ ).

Similar experiments were performed for the thiono analog of 2, i.e., 5. The high activity 


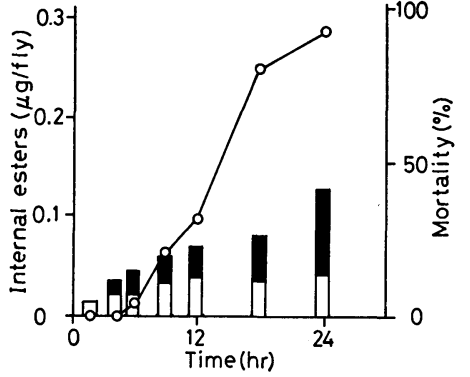

Fig. 6 Internal amounts of 4-n-propyl BP and its thiono analog $(\square)$, and mortality of houseflies $(\bigcirc)$ when the latter compound $(1 \mu \mathrm{g} / \mathrm{fly})$ was topically applied without synergists.

of $\mathbf{5}$ was not directly associated with its penetration process because little, if any, difference was detected in the penetration rate between 2 and 5 (Figs. $3 \mathrm{~A}$ and $3 \mathrm{C}$ ). When houseflies were treated with $\mathbf{5}$ at $1 \mu \mathrm{g}$ per fly without $\mathrm{pb}$, extracts from acetone-rinsed fly bodies contained $\mathbf{2}$ which was formed by in vivo oxidation of 5. At $24 \mathrm{hr}$, the total amount of internal 2 and 5 was about $0.12 \mu \mathrm{g}$ per fly and the mortality reached $90 \%$ (Fig. 6).

\section{DISCUSSION}

Structure-activity relationship studies have established that appropriate hydrophobicity, bulkiness and electronic properties of the bridgehead substituent are very important for high activity. ${ }^{2,10)}$ Such a structural requirement was less strict in the case of insecticidal activity against houseflies than in the case of mammalian toxicity. For instance, 4-t-butyl BP (1) was outstandingly toxic to mice (i.p. $\left.\mathrm{LD}_{50}, 0.053 \mathrm{mg} / \mathrm{kg}\right),{ }^{10)}$ but was not so to houseflies. There was no significant difference in insecticidal activity between 4-t-butyl $\mathrm{BP}$ and 4-n-propyl BP (2). When considered with the ratio of mouse- $\mathrm{LD}_{50} /$ housefly- $\mathrm{LD}_{50}$ (rs), compound 2 ( $\mathrm{rs}=2.2$ ) appears to have higher specificity in action on houseflies than $\mathbf{1}$ (rs= 0.43). ${ }^{2)}$ This could mean that 2 has high affinity for a target site in houseflies and low affinity for that in mice. In this respect, $\mathbf{2}$ is likely a better compound for characterization of a housefly-specific site. This compound has also been used as a radiolabeled ligand in our ligand-receptor binding studies. ${ }^{11,12)}$ For these reasons, 4-n-propyl analogs were chosen for this study.

In a previous paper, ${ }^{2)}$ we reported that bicyclic phosphates including 4-n-propyl BP (2) were not insecticidal as judged from their 24-hr lethal activity when topically applied to houseflies at the dosage of $15 \mu \mathrm{g}$ per fly without $\mathrm{pb}$. In the present study, however, we found that $\mathbf{2}$ penetrated and accumulated slowly in the fly body so that the deaths increased gradually until $96 \mathrm{hr}$ after application (Fig. 1). This finding suggests that the rate of detoxication is somewhat lower than that of penetration. Also, 2 was found to exert toxicity by topical application after pretreatment with $\mathrm{pb}$, being comparable to that determined by injection after treatment with pb (Table 1). Thus, the activity of $\mathbf{2}$ as a contact insecticide was greatly improved by treatment with $\mathrm{pb}$. The integument penetration of $\mathbf{2}$ is slow, as compared with that of other organophosphorus insecticides such as fenitrothion and methyl parathion. ${ }^{13)}$ However, the reason of the improved activity was not the enhancement of the penetration rate of $\mathbf{2}$ because data failed to show any significant difference in the penetration rate of $\mathbf{2}$ between pb-treated and untreated fly bodies (Figs. $3 \mathrm{~A}$ and $3 \mathrm{~B}$ ). The absorbed compound appeared to be successively detoxified by microsomal oxidases because the slow penetration of $\mathbf{2}$, but its internal concetration was raised to the lethal level by the action of the oxidase inhibitor pb. Pretreatment with $\mathrm{pb}$ stabilized a small dose of 2, which then produced rapid and irreversible intoxication. The high toxicity of $\mathbf{2}$ was also obtained by injection which bypassed the integument and raised the internal concentration before significant detoxication could occur.

As shown in Fig. 7, the total recovery of $\mathbf{2}$ applied to houseflies decreased with the elapse of time in houseflies without $\mathrm{pb}$ treatment, whereas such a decrease was not noteworthy in pb-treated houseflies. This finding clearly supports the possibility that oxidation by microsomal oxidases plays an important role in detoxication of $\mathbf{2}$, and that ester hydrolysis is of minor importance. Oxidized metabolites with the cage structure would be detectable by $\mathrm{GC}$ if they were formed, but none of other GC peaks than that of $\mathbf{2}$ was observed. Hence, it 


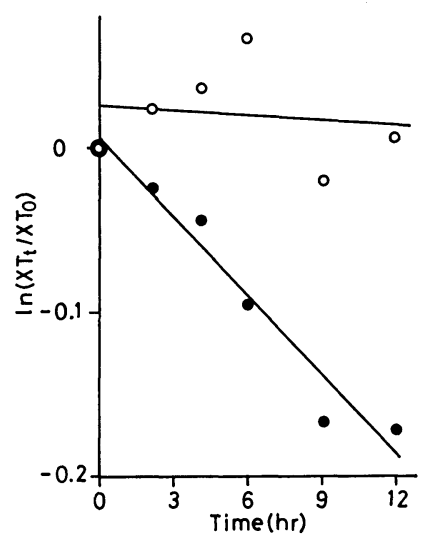

Fig. 7 First-order plots of totally recovered 4- $n$ propyl BP when topically applied at the dosage of $1 \mu \mathrm{g} /$ fly with $(\bigcirc)$ and without $(\bullet)$ pb pretreatment.

$\mathrm{XT}_{0}$ : amounts of total $\mathrm{BP}$ at $0 \mathrm{hr}, \mathrm{XT}_{t}$ : amounts of total $\mathrm{BP}$ at $t \mathrm{hr}$. The lines were drawn by the least-square method.

is possible to speculate that the cage structure characteristic of bicyclic phosphorus esters may be broken down to a ring-opened structure through oxidation at the endomethylene carbon. The above observation is in marked contrast to the finding that hydrolysis products were main metabolites in mammalian species. ${ }^{14}$ ) With regard to the structure of a possible metabolic intermediate, a bridged bicyclic acyl phosphate synthesized by Casida et al. ${ }^{15)}$ is of great interest in view of its instability. The metabolic pathway proposed here can be confirmed by detailed studies using radiolabeled compounds.

4- $n$-Propyl BP caused mortality after $24 \mathrm{hr}$ at the dosage of $12 \mu \mathrm{g}$ per fly while 2 at $1 \mu \mathrm{g}$ or $5 \mu \mathrm{g}$ per fly exerted little effect (Figs. $4 \mathrm{~A}$, $4 \mathrm{~B}$ and $5 \mathrm{~A}$ ). When the level of $\mathbf{2}$ in the fly body reached $0.2-0.3 \mu \mathrm{g}$ per fly, the death was remarkable. At the dosage of $1 \mu \mathrm{g}$ or $5 \mu \mathrm{g}$ per fly the internal level of $\mathbf{2}$ remained below the lethal level, but was easily increased to the lethal level in $6 \mathrm{hr}$ by treatment with $10 \mu \mathrm{g}$ of pb followed by $1 \mu \mathrm{g}$ of 2 per fly (Fig. 5 B). It was noted that the same internal level of $\mathbf{2}$, e.g., $0.3 \mu \mathrm{g}$ per fly, resulted in different mortality shown in Figs. $5 \mathrm{~A}$ and $5 \mathrm{~B}$. This is probably due to the fact that the internal amount does not refer to the level at the site of action. In other words, a considerable amount of $\mathbf{2}$ appears to be taken up by inert tissues other than the target site through gradual accumulation shown in Fig. 5 A.

In contrast to 4- $n$-propyl BP, its thiono (5) and phosphite $(\mathbf{6})$ analogs applied topically were as insecticidal as $\mathbf{2}$ injected (Table 1). The structural difference between $\mathbf{2}$ and $\mathbf{5}$ is just that the phosphoryl oxygen atom of $\mathbf{2}$ is replaced by the thiophosphoryl sulfur atom of 5. The following explanation seems to be possible for the difference in the insecticidal activity between the two compounds by single topical application. First, the markedly high activity of $\mathbf{5}$ cannot be accounted for by its integument penetrability, which was as low as that of 2 (Fig. $3 \mathrm{C}$ ). Second, the inhibitory activity of specific $\left[{ }^{3} \mathrm{H}\right] 4-n$-propyl BP binding to housefly head membranes has been measured as an indication of the intrinsic activity of $\mathbf{2}$ and $\mathbf{5}$ at the target site. ${ }^{12}$ The inhibition constants $K_{i}$ were $4.3 \pm 0.9 \mathrm{~nm}$ and $27.2 \pm 6.2 \mathrm{~nm}$ for $\mathbf{2}$ and 5, respectively. 4- $n$-Propyl BP was more potent than $\mathbf{5}$ in displacing specifically bound $\left[{ }^{3} \mathrm{H}\right] \mathbf{2}$, but the potency of $\mathbf{2}$ may be overestimated because this is the case that the displacer is the same compound as the radiolabeled ligand. With this fact taken into account, there seems to be no essential difference in the intrinsic activity between them. Third, Fig. 6 shows that the mortality at $24 \mathrm{hr}$ was near $100 \%$ while the internal level of $\mathbf{5}$ and its oxidized metabolite $\mathbf{2}$ was lower than the lethal level described above $(0.2-0.3 \mu \mathrm{g} / \mathrm{fly})$ in the case of topical application with $1 \mu \mathrm{g}$ of $\mathbf{5}$ per fly. At this level, $\mathbf{2}$ is not very effective but $\mathbf{5}$ appears to be critical. The internal lethal level of $\mathbf{5}$ is considered to be approximately $0.03 \mu \mathrm{g}$ per fly. This is close to the low $\mathrm{LD}_{50}$ value $(0.061 \mu \mathrm{g} / \mathrm{fly})$ for $\mathbf{5}$ with $\mathrm{pb}$ (Table 1). As mentioned above, the accumulation of such an amount of $\mathbf{2}$ was also observed in topical application of $\mathbf{2}$ at $1 \mu \mathrm{g}$ per fly (Fig. $4 \mathrm{~A})$, although it was much lower than the lethal level. One-tenth of the internal lethal dose of $\mathbf{2}$ is enough for $\mathbf{5}$ to cause death in houseflies. The thionate ester may reach the target in nerve tissue more efficiently than $\mathbf{2}$ because of its higher hydrophobicity $(\log P=$ 1.4) than that of $2(\log P=0.0)$. In order to 
increase the internal amount ten times in 24 hr without pb treatment, more than ten times dose is needed for topical application due to its slow penetration (Figs. 4 and 5). This is a possible cause of the big difference in insecticidal activity between $\mathbf{2}$ and $\mathbf{5}$.

Figure $3 \mathrm{~A}$ shows the biphasic proceeding of penetration of 2. The data in Figs. $3 \mathrm{~B}$ and $3 \mathrm{C}$ may be also biphasic although the lines were drawn by the least-square method. Biphasic phenomena have been also reported in the penetration of various insecticides. ${ }^{16,17)}$ Acetone in which $\mathbf{2}$ was dissolved may work as a carrier to produce the first steep phase. Alternatively, there might be a saturable pool which absorbs a definite amount of chemicals rapidly in the integument, and then releases them inside the body. The former explanation seems to be more conceivable but no detailed studies have been done in this regard.

In conclusion, 4- $n$-propyl BP was so slow in penetration to the housefly body and was so susceptible to microsomal mixed-function oxidases that it was inactive as a contact insecticide. However, the activity was greatly improved by pretreatment with the microsomal oxidase inhibitor $\mathrm{pb}$ or by injection, though the ester was still less active to houseflies than to mice. The topical insecticidal activity of the thiono and phosphite analogs was in a range similar to that of the oxon analog by injection. The high activity of the thiono analog is associated with its lower internal lethal level than that of 4-n-propyl BP.

\section{ACKNOWLEDGMENTS}

The authors acknowledge Professor M. Eto for his valuable suggestion and kind encouragement. Thanks are also due to Mr. J. Wada for his technical assistance. This paper was presented at the West Japan District Annual Meeting of the Agricultural Chemical Society of Japan held in Miyazaki, October 1985.

\section{REFERENCES}

1) E. M. Bellet \& J. E. Casida: Science 182, 1135 (1973)

2) Y. Ozoe, K. Mochida, T. Nakamura, A. Shimizu \& M. Eto: J. Pesticide Sci. 8, 601 (1983)

3) N. G. Bowery, J. F. Collins \& R. G. Hill: Natuve 261, 601 (1976)

4) S. Korenaga, Y. Ito, Y. Ozoe \& M. Eto: Comp. Biochem. Physiol. 57C, 95 (1977)
5) C. J. Roberts, V. A. James, J. F. Collins \& R. J. Walker: Comp. Biochem. Physiol. 70C, 91 (1981)

6) M. K. Ticku \& R. W. Olsen: Neuropharmacology 18, 315 (1979)

7) R. F. Squires, J. E. Casida, M. Richardson \& E. Saederup: Mol. Pharmacol. 23, 326 (1983)

8) F. Matsumura \& K. Tanaka: "Cellular and Molecular Neurotoxicology," ed. by T. Narahashi, Raven Press, New York, p. 225, 1984

9) Y. Ozoe \& M. Eto: Agric. Biol. Chem. 46, 411 (1982)

10) M. Eto, Y. Ozoe, T. Fujita \& J. E. Casida: Agric. Biol. Chem. 40, 2113 (1976)

11) Y. Ozoe, K. Mochida \& M. Eto: Agric. Biol. Chem. 46, 2521 (1982)

12) Y. Ozoe, M. Eto, K. Mochida \& T. Nakamura: Pestic. Biochem. Physiol. in press

13) R. M. Hollingworth, R. L. Metcalf \& T. R. Fukuto: J. Agric. Food Chem. 15, 250 (1967)

14) D. S. Milbrath, M. Eto \& J. E. Casida: Toxicol. Appl. Pharmacol. 46, 411 (1978)

15) J. E. Casida, M. Eto, A. D. Moscioni, J. L. Engel, D. S. Milbrath \& J. G. Verkade: Toxicol. Appl. Pharmacol. 36, 261 (1976)

16) N. Sinchaisri, T. Miyata \& T. Saito: J. Pesticide Sci. 3, 249 (1978)

17) C. Collins, J. M. Kennedy \& T. Miller: Pestic. Biochem. Physiol. 20, 25 (1983)

\section{要 約}

\section{イエバエに対するニ環リン酸エステル類の殺虫} 活性に影響を及ぼす皮膚透過と代謝

尾添嘉久，狩野浩之，持田和男，中村利家

藤井 誠

オキソン型 4 位 $n$-プロピル基置換二環リン酸エステ ル (4-n-プロピル BP) のイェバェへの局所施用法によ る殺虫活性はピペロニルブトキシド $(\mathrm{pb})$ の作用で著し く高められた（共力効果比 313）．4 種の異なった施用法 による 4-n-プロピル BP の殺虫活性 (24 時間後の $\mathrm{LD}_{50}$ 值, $\mu \mathrm{g} /$ 頭) は, $\mathrm{pb}$ 処理注射 $(0.169)>\mathrm{pb}$ 処理塗布 (0.212) >注射 (0.449)》塗布 (66.4) の順となった、イ エバェに持ける 4-nープロピル BP の代謝には酸化酵素 が非常に大きな役割を果たしている，皮膚透過の速度は 遅いが，酸化酵素の阻害あるいは注射法によって 4-nプロピル BP の体内レベルを $0.2 \sim 0.3 \mu \mathrm{g} /$ 頭まで高める と著しい致死が見られた。一方，チオノ体およびフォス ファイト体は単独局所施用でも高い殺虫活性を示した. チオノ体の高い殺虫活性は皮膚透過性, あるいは作用部 位での活性が高いためではなく，致死を引き起こす体内 レベルが低いことと関連している. 